\title{
Diferença e vantagem da sedução cética
}

Difference and Advantage of the Skeptical Seduction

\author{
Cesar Kiraly \\ Universidade Federal Fluminense \\ Ciência Política
}

\section{RESUMO}

Trata-se de apresentar os caminhos de uma abordagem cética em relação à política e seus mecanismos de sedução, bem como a sua imprevisibilidade.

\section{PALAVRAS-CHAVE}

Ceticismo; Política; Ética.

\section{ABSTRACT}

The essay aims to present the paths of a skeptical approach of politics and its mechanisms of seduction, as well as its unpredictability.

\section{KEY WORDS}

Skepticism; Politics; Ethics. 
A linguagem é facilmente capturada pela pretensão de interromper o movimento da experiência. Ela nos induz a esquecer que o predicado nada mais é do que dinamismo ${ }^{1}$. Isso justifica o cuidado do cético com a linguagem, pois ainda que não se esqueça dos perigos imobilizadores da expressão, o problema não é interno ou individual, saindo um tanto do seu âmbito de autonomia, donde pode acabar por efeitos opostos ao seu desejo. Assim, muito embora não se possa dominar a expressão, e nem é o caso de almejar isso, o cético busca compatibilizar a captura que a linguagem implica com a vontade de perceber a experiência em fluxo.

Por essa razão, o cético assume uma postura pictorialista, de impactos exemplares para a descrição do fenômeno político, fundamental para o olho moral que demanda. Porque o pictorialismo inabilita o cético, no mais que tal é possível, à competição, e, nessa medida, é capaz de oferecer elementos para que se perceba a política mais de perto, para além da ilusão da polaridade entre amigo e inimigo. A descrição apurada do fenômeno político permite que nuances da ambivalência apareçam, donde a amizade e a inimizade sáo feitas em sentimentos complementares, no que concerne aos mesmos objetos, de atração e repulsão. Por isso caráter ilusório da amizade ou da inimizade.

Ainda que tenha, em algum momento, de se questionar sobre o caráter abstrato, sempre presente, da imagem que descreve, no mais das vezes, o cético pratica uma forma de figurativismo. Há cópia explícita à forma de localidades e pessoas, paisagens e retratos, que podem ser reconhecidas, inclusive. Ao se referir a algo que não é ainda visto, o tipo de descritividade que realiza contribui para o incremento da percepção. A ideia é que ele vê melhor porque presta mais atenção. A relação com o objeto é de suma importância, pois é ela que estimula a intensidade, e o apego aos detalhes, ao se falar. No que concerne à utilidade, o fato do cético se interessar pela crueldade, a ela ser especialmente sensível, é de relevância à moralidade e à política. Imerso que nela está não permite que passe desapercebida e se aprofunde. A questão, todavia, não é, para o cético, a de pintar a crueldade para a qual está preparado, porque essa é menos problemática do que aquela à qual ainda não é capaz de ver e identificar.

A figuração é a regra, mas ignorar o abstrato, o informe do pigmento, tornaria impossível manejar os componentes até chegar a uma representação apropriada. Se os modos de estabelecimento da imagem são manejados sem a consciência dos pigmentos, entấo a linguagem é empregada de maneira dura e náo se amolda ao fenômeno. $\mathrm{O}$ cético representa a crueldade para a tornar realidade para quem não a consegue ver. Trata-se de um embate pictórico de resultados morais benignos. Pode-

1 Barthes, 2003, p. I28. 
se dizer que é a imprevisibilidade dos efeitos da sedução que levaram à morte de Sócrates. $\mathrm{O}$ método socrático de andar pela cidade não se furtando a discussôes, a disposição para se afastar da pólis para restar embaixo de alguma árvore e se investir em conversas, ou mesmo a sua famosa capacidade de guerreiro e resistência ao frio e a fome, tudo isso pode ser encarado como formas da sedução. Mesmo a interpretação de que ele se permitia ser condenado à morte, ao invés de se valer de argumentos falsos, mas persuasivos, uma vez que todos temos certeza de que facilmente escaparia das acusaçóes se quisesse, por tâo fantásticas serem suas habilidades como homem que fala. A decisão de não fugir, de morrer como livre e ateniense, também exerce profundo poder de atração.

A responsabilidade da postura democrática é intensamente atraente. Do outro lado, a, por assim dizer, irresponsabilidade sofística, a disposição de fabricar um desvio no mundo pela palavra, da precedência do náo-ser sobre o ser, do homem e suas mentiras como medida de todas as coisas, de um dia defender bem uma tese, e no outro ainda melhor a argumentação contrária, absolver Helena de Tróia, e sua sedução involuntária, com a mais elaborada das formas de seduzir, tudo isso também é bastante sedutor.

A sedução está por todos os lados. Tanto na fortaleza virtuosa de Sócrates, quanto nas capacidades demiúrgicas de Górgias, para falar de personagens que ocupam o centro, mas buscar estar do lado de fora e tornar evidente o quáo risível é tal dinâmica de capturas, como faria um cínico, da mesma forma é bastante atraente. Até aqui ninguém diz quem pode ou não seduzir: trata-se de um poder, seduz quem pode seduzir.

A vida democrática do século $\mathrm{V}$ é a que melhor nos expóe aos perigos e delícias da sedução. A mera migalha de autocracia é suficiente para interromper tal tiroteio, na medida em que diz por quem devemos nos permitir ser atraídos ou quem pode estar na posição de exercer magnetismo. Num mundo eivado de hábeis sedutores, somos induzidos a nos indagar acerca dos seduzidos. Seriam os sedutores, de alguma forma, responsáveis por aqueles a quem seduziram, é a pergunta que se nos avizinha.

Um total controle sobre os efeitos da sedução seria impossível e mesmo um absurdo, mas tomar essa indeterminação de chegada como ponto de partida seria imensamente irresponsável. Como assim? Se tomarmos o fato dos afetos provocados na sedução serem incontroláveis como salvo conduto para não nos ocuparmos com os efeitos, seremos invariavelmente irresponsáveis.

Digamos que a sedução é doce onde a argumentação é dura. Argumentar, o que defensivamente pode ser chamado de retórica, dá-se no esforço de soterramento do rival. No confronto argumentativo, o objetivo é vencer. Ser vitorioso, pelo menos no sentido triunfal, é obter do adversário o reconhecimento de que se tem razão. 
Por certo, ter razão ajuda muito a vencer uma discussão, mas não é necessário. Um bom retórico é aquele que extrai do oponente a afirmação de que se está com a razão, mesmo que não se esteja com ela, no caso de admitirmos que isso é possível. A sedução pode até se apresentar sub-repticiamente no processo de se ter a razáo admitida, se assim for, pode ser que não haja embate, ou que seja muito tênue. A necessidade de argumentar é um forte indicativo de que talvez a sedução não esteja mais a operar efeitos. Não é que não se possa pensar ou criar num embate, há acontecimentos notáveis que são ocasionados por ambiente de pressão, mas isso não é muito fácil. De forma geral, podemos dizer que o objetivo do embate é dobrar a vontade do oponente. Há quem seduza por formas conflitivas de sedução, daí é apenas um estilo e não um confronto, como na filosofia analítica.

Por outro lado, a sedução é extremamente propícia para a criação e para o pensamento, porque essa envolve certa dose de cumplicidade, mesmo na frieza, quando é o caso, em que o sedutor e o seduzido, se se pode estabelecer quem é quem, permitem-se ir juntos para onde dificilmente seriam capazes de chegar sozinhos. Podese dizer que a argumentação é uma técnica e a sedução uma poética. Posto, a sedução é a entrega bilateral de parte da vontade. Por isso, por náo ser uma espécie de combate, pode ser praticada, sem injustiça, por pares bastante desiguais, como, por exemplo, a relaçáo entre o mestre e o discípulo. A sedução é se permitir levar para onde não se sabe exatamente, mas estar disposto à empreitada não parece ser algo que se possa escolher.

Temos consciência de que na sedução todos sabem o que está acontecendo, de tal forma que a ninguém é permitido ser seduzido além do preparo e da disposição a sê-lo. Não resta dúvidas sobre o fato de que seduzir é um fenômeno e enganar é outro completamente diferente. Está certo que nem o vínculo com a inspiração a absolve de seus acusadores, e sim, o belo desempenho argumentativo é mais impressionante do que a sedução, pois naquele, tudo está dirigido a ser pequeno, logo, o bom desempenho argumentativo deve ser premiado, entretanto não justifica a boa imagem da argumentação diante da péssima possuída pela sedução. A referência externa tomada pelos céticos é sempre a figura de Pirro de Élis. Ele é ao mesmo tempo um pouco Sócrates e um pouco Górgias. A sedução é exercida na vida comum, mas ela não se dá pela busca do que as coisas são, e sim justamente pela impossibilidade de fazê-lo, positiva ou negativamente. Donde exercer uma sedução um pouco estranha. Pelo que será mais tarde chamado de suspensão do juízo, Pirro supostamente precisaria ser protegido de cáes ferozes ou desviado de buracos, de jeito possível de ser remetido a Tales de Mileto, posto não poder saber se o cão é mesmo feroz ou a queda iminente. Se essas anedotas sobre a captura da vontade exercida por Pirro são verdadeiras, é certo que isso não se dava o tempo todo. 
Ademais, mesmo participando da vida, Pirro possui alguns traços pré-socráticos, em virtude dos momentos de reclusáo e de ficar em casa no exercício de tarefas pouco filosóficas e mesmo vergonhosas para o período, como lavar animais etc. A relação com os discípulos também não é muito usual, na medida em que os seduz, exerce sobre eles uma responsabilidade, mas o faz impedindo que o vínculo de mestria se arraigue, uma vez que pressuporia um saber julgado impossível por ele, por assim dizer. Pirro agiria de modo distinto a um cínico, ou a um cirenaico, entretanto, teria em comum, principalmente com os cínicos, o fato de causar assombro em algumas de suas açóes. Pirro não buscava assombrar, chocar por tentar mostrar alguma coisa sobre a suposta natureza das convençôes ou suas eventuais hipocrisias, o que não quer dizer que, ao não tomá-las como verdadeiras, ou não festejar as suas razóes, náo produza algum efeito de explicitação de dinâmicas sem sentido.

Este é o percurso que intendemos percorrer: montar a especificidade da sedução cética e de suas ferramentas antigas e novas. Outrossim, julgamos ser o caso de direcionar para possíveis consequências políticas dessa forma de seduçáo se comparada com o efeito da moralidade da sedução dogmática. Isso quer dizer que ensaiamos mostrar que a sedução exercida pelo cético nos parece melhor do que a praticada pelo dogmático, principalmente no que concerne aos efeitos para a vida pública. Buscaremos demonstrar, a partir de elementos que ainda seráo apresentados, que a sedução praticada pelo dogmático tende a se eximir em relaçáa ao seduzido, justamente na proteção que guarda ao sedutor, tomado como melhor, ou até mesmo superior, de forma que mantém a crueldade da sedução encoberta. A sedução exercida pelo cético, parece-nos, ao insistir na exposição do sedutor, e conservar sempre o desamparo em questáo, mantém a crueldade explícita, e, portanto, sem produzir os efeitos de imoralidade sobre a vida política.

O ceticismo oferece não uma resposta, mas algo a se fazer. É natural que em se repetindo muitas vezes a mesma coisa, e comparando os resultados, comece-se a se tornar bom na atividade. Ainda que náo haja uma forma certa de praticar o ceticismo, pode-se perceber o aprofundamento de uma prática. Um cético não diz "você não é cético", e sim "você não foi suficientemente cético". É profundamente sedutor entrar em uma atividade de rigor na qual não se pode dizer qual a forma certa de a cultivar, apenas apontar a falta de intensidade. Além disso, descrever é uma atividade sedutora, porque pressupóe um intenso envolvimento com as coisas por elas mesmas, é sedutor ocupar uma posição de se deixar fascinar de forma não perturbada. Ao contrário de outras posiçôes, o ceticismo concerne ao interesse pela forma como as coisas estáo. No que concerne a descrever à moda de Agripa, aparentemente o cético estaria a perder tempo ao se dedicar a perceber algo que o distrairia do próprio ceticismo, mas não, seja lá o que vier a prender a atenção do cético, ele precisa de 
todo o ceticismo para proceder a descrição. Ainda que não saiba o que vai fazer, se demandado sobre o que o ocupa, ele pode descrever o que faz, daí parece que o cético, de uma perspectiva externa, parece estar sempre fazendo a mesma coisa. A palavra chave aqui é investigação. Ele está sempre investigando.

Apesar de toda a dívida que a ciência moderna tem com o ceticismo, este não parece ser movido pela curiosidade, porque esta se preocupa precipuamente com o funcionamento daquilo que a intriga. Logo, diante de algo trivial, não haveria o que investigar, uma vez o enigma do mecanismo decifrado. A descrição pode até mesmo decifrar um enigma ao exaurir muitas perspectivas de certo caminho, a suposta crise da razão seria desencadeada por isso, depois de tanto descrevê-la, o ceticismo acabaria com seu mistério, mas o ponto é que se movida pela curiosidade, ou a descrição se tornaria um vício ou chegaria a um fim. A investigação é movida por sua capacidade de se deslindar da perturbação. $\mathrm{O}$ cético investiga, porque fazê-lo o mantém tranquilo. Ele não quer o saber, muito embora acabe produzindo algum, e sim a tranquilidade obtida quando seus olhos pousam sobre o que aparece. $\mathrm{O}$ dogmático está preocupado em não ser enganado pela água do rio que faz o remo parecer quebrado ou pela distância que torna uma pessoa do tamanho de um moinho de vento. O cético náo se preocupa com isso, ainda que em sua prática acabe realizando tais modos divertidos pelos quais a aparência aparece. Outrossim, nota em sua investigação dos discursos que cada pessoa diz uma coisa diferente sobre o que aparece. A pluralidade não é perturbadora. Mas se estiver acompanhada, principalmente quando composta de enunciados filosóficos, de número idêntico, ou superior, de pretensóes de verdade, pode sim levar a algum sofrimento. Estas pretensóes de verdade fazem o cético assistir algo que o faz sofrer, o sofrimento do dogmático em querer ter a verdade, sua vontade de agarrar sem poder. As dores do mundo causam sofrimento e produzem perturbação, mas são tornadas ainda piores quando associadas com a pretensão de saber a verdade. Aquele que já se fiou num dogma sofrerá pelo descompasso entre sua crença e o mundo, mas também não será fácil a vida de quem ainda não se decidiu entre vários, se é que ter um dogma é realmente questáo de escolha. A pretensão perturba a indiferença, ela induz a tomar certas diferenças como mais diferentes do que outras, como se fossem entrevisóes da verdade que estaria por trás da aparência. A oposição de argumentos revigora a indiferença e restitui a equipolência necessária para a descrição. A equipolência é o que permite a suspensão do juízo, estado em que se pode começar a descrever. A tranquilidade segue a suspensão como a sombra segue o corpo.

O percurso dogmático inicia-se com a afasia. A afonia do dogmático é não conseguir dizer e mesmo assim buscar formas claudicantes para fazê-lo, de tal forma que é constituída uma fala remetida a essa incapacidade de origem. O dogmatismo, nesse 
sentido, defende o lugar da insistência numa forma da gagueira, como reação a afonia. Se o cético fosse instado a lidar com a afonia dogmática, ele julgaria que precisaria se tratar antes de rodar em falso na insistência da fala. Isso se dá porque, para o dogmático, é questáo de honra mostrar na fala que viu algo cujo resultado natural seria lhe caçar a voz.

A afonia, para o dogmático, ocorre da seguinte forma: (I) no início ele possui comportamento doutrinado, segue a versão da verdade de alguém que a viu, e que, provando-o, gagueja. A despeito do fato de poder existir um cansaço na versão seguida, decorrente, muitas vezes, de ser tão repetida para ser ensinada, a verdade se justifica, porque o dogmático doutrinado sente uma forte angústia, esta lhe serve de indício sobre a existência do que está por detrás das coisas; se um discurso cansado é tudo o que há para dar conta dessa angústia, ora, que seja, porque isso é melhor do que não ter nada. (2) Acidentalmente, por decorrência de seus estudos, ou não, uma vez que uma das formas de lidar com a angústia da verdade é se entregar aos vícios, nem que seja ao vício constritivo, o dogmático vê a verdade, não toda ela, algum signo que dela sirva de índice mais fiável do que sua própria angústia, mas em núpcias harmônicas com essa. Daí o que faz o dogmático, portador de uma evidência da verdade? (3) Ele quer contar a outras pessoas. Ao tentar falar, percebe que a verdade é muito maior do que suas capacidades de colocá-la na linguagem, aliada à compreensível excitaçáo, o que acontece? Ele tenta falar e não sai voz. A afonia o deixa ainda mais nervoso. Então ele insiste, insiste, até que sons estranhos começam a sair de sua garganta, com o tempo a voz lhe retorna, mas inexoravelmente marcada pela afonia que tenta superar. $\mathrm{O}$ dogmático que adquire uma versão vigorosa da verdade, pelo menos no início, não mais cansada, porque sem doutrina, começa a gaguejar. O álibi da gagueira, como dissemos, é que ela mesma é signo da experiência da verdade que o autoriza a falar. Por não ter visto a verdade por completo, o discurso dogmático é incompleto, mas visando obter a completude por artifícios intelectuais, de modo que esses indiquem os pedaços da verdade que nunca foram vistos. $\mathrm{Na}$ modernidade estes artifícios são agrupados sob o nome sistema.

Tanto a afonia cética, quanto a dogmática, exercem formas de sedução. A dogmática a partir da promessa de acesso ao invisível a que serve de índice pela fala hesitante, via pela qual se estruturarão as modernas teorias da representação. A cética se baseia na incongruência do distanciamento entre signo e coisa. Ora, o signo é antecipação da coisa como a fumaça e o fogo, pois bem, ele é a coisa. Logo se pode depreender que a afonia cética é oposta a admissão do signo como evidência do invisível. Isso quer dizer que a sedução cética é exercida pela interrupção das prerrogativas da fala, tal como a existente na relação doutrinária. $\mathrm{O}$ dogmático espera que o discípulo se engaje em diálogo de esclarecimento em que os resultados são previstos, 
a saber, a aceitação do que foi visto. Além disso, por estar enfrentando a afonia, resultante do vislumbre da verdade, o mestre espera que os ouvintes se submetam às fraturas da sua fala. $O$ cético conversa, não dialoga no sentido filosófico, porque não sabe onde irá chegar, se conduzirá, se será conduzido, se se comporá ou se frustrará as expectativas. A própria frustração advinda da imprevisibilidade do cético é modo de boicotar a pretensão de verdade. Assim, a sedução da fala cética é que ela não precisa romper o silêncio. Ele pode simplesmente não dizer nada. Se diz, ninguém precisa ouvi-lo. Esta é a especialidade da sua sedução: a gratuidade. Não há bem nada a ensinar e nada a aprender. Isso não quer dizer que os céticos não ensinem, apenas que não há nada que precise ser ensinado ou uma ordem certa para fazê-lo. O cético é sedutor ao frustrar a verticalidade entre mestre e discípulo. Se estóicos e epicuristas podiam ser reconhecidos pelas roupas, se até mesmo a diferença de hierarquia podia ser por elas depreendida, isso não era possível entre os céticos, pois se vestiam como qualquer um. Penso que não seria estranho que um cético, eventualmente, pudesse se vestir como estoico ou epicurista, reconhecendo-os como modos de ser qualquer um. Existir como um cético, não seria um problema.

Senso comum, dogmatismo e ceticismo se aproximam e se afastam por razóes distintas. Parece, todavia, haver um ponto de partida comum aos três que é especialmente problemático ao cético. A maior parte dos enunciados a que assentimos o fazemos sem perceber. Diante disso o dogmático, no processo de esclarecimento, selecionaria os melhores e excluiria os piores. A empresa dogmática seria levada adiante para ajudar o senso comum a sair do estado de cegueira que o caracterizaria. Assim, por mais que um homem do senso comum pudesse aderir, sem perceber, a uma sentença dogmática, ele seria ainda suspeito, enquanto não abandonasse a posição ocupada. Apesar de parecidos, o objetivo do dogmatismo seria o de suplantar qualquer necessidade residual de senso comum, além de responder as objeçôes céticas. Cada dogmático monta um cético segundo seu desejo, mas há constância: ou julgam que o cético sabe que o ceticismo é impossível, donde ele exerceria uma prática exclusivamente sedutora, mal intencionada, portanto; ou é um tolo que não percebe que é impossível. Ainda na insistência, caberia ao dogmático denunciar o momento em que o cético estaria em flagrante delito de não ser cético. No meio tempo, pedem que o cético realize tarefas estranhas, como se atirar contra a parede, pular de um penhasco, beber veneno, que toque o vidro incandescente com as mãos etc.

É claro que a possibilidade de se armar uma arapuca para o cético se deve a uma má compreensão do ceticismo. Seria como dizer a um sapateiro que é impossível ser sapateiro, uma vez que se fez mal um sapato. Um sapateiro não se torna sapateiro 
por fazer um sapato perfeito, mas por saber fazê-lo. É a mesma coisa para o ceticismo, seu sapato é a suspensão do juízo e a descrição. O cético, de partida, é um homem como qualquer outro, a única diferença é que aprende a fazer algo que nem todo mundo sabe fazer. Ele pratica o seu ceticismo fazendo para si uma vida sem crenças. Uma perfeita vida sem crenças seria um contrassenso. A vida sem crenças não é um ideal, e sim o nome genérico daquilo que o cético sabe fazer. Pode-se não gostar do modo como um sapateiro trabalha e muito apreciar o resultado, ou o inverso, ou não gostar de nada, mas ainda gostar de sapatos. Pois bem, há quem não suporte a suspensão do juízo, talvez essa pessoa não tenha sido feita para sapatos. Mesmo quem sabe fazer sapatos, pode gostar mesmo de usar os feitos por outra pessoa, todavia, é necessário, para um cético, que, sob necessidade, saiba fazer os seus próprios. Se a suspensão do juízo é como fazer sapatos, está certo que são apenas os feitos sob medida, em virtude da impossibilidade de se determinar padróes de tamanho. A suspensão do juízo é sob medida ou não é.

Parte da eficácia da sedução exercida pelo dogmático se deve a esse se apresentar como o proprietário do conceito. Nessa medida, o conceito seria ao pensamento o que a verdade, supostamente, é para a natureza, um acesso às coisas mesmas. Mais ainda, o conceito seria o modo próprio do pensamento para abrigar e compreender a verdade. Ele seria muito mais estável do que uma descrição. Daí, o cético seria o sem conceito. Essa percepção do ceticismo parece equivocada. Porque o cético reconhece a especificidade do conceito, só náo admite que nada seja como ele. O conceito seria uma bela operação imaginativa, cujo elemento problemático seria a pretensão dogmática com relação a ele. Daí, afastado dessa forma de exigência, ele se mostraria como o mais sofisticado modo de operaçáo da imagem, presente, por exemplo, na instituição voluntária de crenças, nos modos de fabricaçáo dos mundos. A sedução cética se exerceria justamente na percepção de que o conceito é uma imagem como as outras, que sua ação de permanência de se dá como crença, como em qualquer imagem. Para um dogmático, não há diferença entre ter ou fazer um conceito, além de que estariam abrigados sob a ideia de descoberta. O cético faz conceito, inventa-o, mesmo que de modo indireto, a partir da prática descritiva, mas não tem um conceito. Pois ter um conceito causa imensa perturbação. Se fosse para ter um conceito, certamente o cético teria a suspensão do juízo. Todavia, mesmo ela é causa de perturbação quando tida. É preciso perceber, assim, que a suspensão, além de ser feita sob medida, possui uma vida útil. Depois de usada por certo tempo, ela gasta e é preciso a jogar fora e conseguir uma nova. Pode ser que a nova suspensão não vista como a antiga, mas a vida é assim mesmo.

As imagens enquanto crenças podem ser compreendidas em três âmbitos: (I) no da impregnação, elas são adquiridas de modo inconsciente. Podem ser naturais, 
como respirabilidade do ar e a queda dos objetos, ou afetivas, tanto em situaçóes elementares, como a expectativa de proteção e de leite, por um bebê, quanto a descodificação de formas elaboradas de expressóes faciais, tons de voz etc. As crenças assim adquiridas são aquelas que nos permite estar no mundo, tão somente isso. Não se apresentam como juízo. Até mesmo as práticas podem ser aprendidas por impregnação, como a língua materna, sem qualquer necessidade de assentimento ${ }^{2}$. (2) $\mathrm{O}$ assentimento é muito mais amplo do que o julgamento e se dá às experiências que estáo diante de nós, conforme nossos sentidos. Essas podem aparecer ou ser levadas a aparecer, a partir de um relato, por exemplo. Os céticos assentem a tudo o que aparece, mesmo que isso implique em um engano, o fato é que as aparências mudam as formas como aparecem, momento em que o assentimento deixa de ser necessário, em virtude da impregnação, começando a operar no primeiro âmbito ${ }^{3}$. Segundo Burnyeat, se o cético assente é porque a coisa se imprime nele, empurra-o, fá-lo reagir compulsoriamente ${ }^{4}$. A aparência nele se impele, mas também o impele, como na fome, no desejo sexual etc. $\mathrm{O}$ assentimento não espera a impregnação para ser reconhecido. (3) Essa forma de assentimento, contudo, não se confunde com o assentimento a um julgamento, porque nele a espontaneidade é interrompida pela afirmaçáo do ser do estado ou do valor. Os idiomas que distinguem o ser e o estar são ideais para fazer entender a especificidade do assentimento evitado pelo cético. Ele admite que o mel está doce, mas não que o mel é doce. Ao se dizer que o cético vive, pelo uso da suspensão do juízo, uma vida sem crença, está-se a referir apenas ao assentimento a um julgamento e não à impregnaçáo ou ao assentimento puro e simples.

A seduçáo exercida pelo cético habita o oferecimento de uma forma consciente de lidar com as emoçôes. Essas, como bem sabemos, são fonte de felicidade e de perturbação. A viabilidade do ceticismo não concerne a viver sem sofrer, mas a fazêlo sem sofrer indevidamente. O ceticismo começa no momento em que o sujeito se dá conta que o seu sofrimento não deriva todo do acontecimento sofrível, mas que boa parte concerne à perturbação acrescida. As emoçôes se compóem com as crenças. Náo é possível se esquivar das emoçóes que derivam da impregnação ou do assentimento. Além de nem ser desejável fazê-lo, posto que são o que permite o vínculo social. Todavia, o assentimento a um julgamento nada muda no vínculo. O cão está perigoso e não é perigoso. Assumir que o ser do cão é perigoso é apenas sentir mais medo. Um outro exemplo mais poético, seria a diferença perturbadora entre ser a fome que se sente e estar com fome. A fome de ser a forme não pode ser

\footnotetext{
2 Barnes, 1998, p. 84.

3 Burnyeat, 1998, p. 40.

4 Barnes, I998, p. 42.
} 
saciada, ao passo que é do estado, de estar com fome, a tranquilidade de sua sucessão ${ }^{5}$. O cético vive sem ter um tipo específico de perturbação. Os acidentes ajudam a sedução cética, ao acrescentarem a ela um charme invulgar. $\mathrm{O}$ principal concerne à suspensão do juízo. Esta pedra angular do ceticismo é traduzida como dúvida nos Academica de Cícero. É deveras sedutor que a suspensão comece a poder ser lida como dúvida a partir de uma opção interpretativa. A epoché é feita em dubitare. Não há nada de imediatamente errado com a dúvida. Aliás, o ceticismo é tão ligado a ela que é reconhecido como a filosofia da dúvida e não da suspensão do juízo. É uma qualidade da tradição descritiva do ceticismo ser capaz de incorporar tudo aquilo que a permite ver melhor. Aceitar a dúvida é aprender a lidar com uma série de equívocos e tirar vantagem deles. Ora, a dúvida é perturbação. Como então o ceticismo poderia aceitar a dúvida, como parte de sua sedução, sem ser destruído por ela? Parte do seu efeito de sedução tem que ver com enfrentar esse risco.

Há pontos em comum entre a dúvida e a suspensão do juízo. Se decompostas teriam partes em comum. A tranquilidade inerente à suspensão do juízo torna o cético bastante atento às imagens. Assim, mesmo que não esteja descrevendo em voz alta ou por escrito, realiza-o mentalmente. A pictorialidade da experiência salta aos olhos dos discípulos do pintor Pirro. A dúvida também provoca uma especial atenção, mas combinada com a angústia da curiosidade. $\mathrm{O}$ cético não quer desvendar os segredos da natureza, não é por isso que ele descreve, mas sim porque sente prazer em aprofundar o seu gosto. A dúvida atenta às imagens com a intenção de fazer algo com elas. Mas o importante não é encontrar um uso, mas proceder a um acúmulo. Tanto a dúvida, quanto a suspensão do juízo, levam ao autoconhecimento e desencadeiam ecos de interioridade. $\mathrm{Na}$ dúvida e na suspensão existe conversa de si para si. A dúvida tende à hipóstase do $\mathrm{Eu}$, mas isso não quer dizer que não tenha mecanismos para fugir dela. Para que a dúvida não perca seu sentido, ela também não pode enunciar de um modo trivial. Porque dizer seria, em última instância, sair da dúvida. Daí a dúvida e a suspensão se encontram, porque o enunciado, em ambos registros, precisa encontrar artifícios formais de purgar a contradição de dizer. Isso quer indicar que tal aparente sofisticação enunciativa tem como função permitir a renovação do sentido para além do inexorável. Sem tal ardil a dúvida e a suspensão seriam apenas o pretexto de um dogma.

A dúvida possui vários sentidos. Dentre eles, claramente, um objetivo e um subjetivo. O primeiro é abarcado pelo espírito científico, como estratificação da curio-

\footnotetext{
5 Burnyeat defende posiçāo bem distinta. Ele julga que o cético está disposto a enfrentar o risco de sua vida ser sem sentido, se o sentido da vida é associado a enfrentar as perturbações. Burnyeat, 1998, p. 42 e 45-46.
} 
sidade, nesse sentido a dúvida faria com que a investigação não pudesse ser interrompida. O segundo concerne aos efeitos internos da dúvida, à sensação íntima de dor sentida por aquele que vive o estado de divisão. Se no sentido objetivo a dúvida implica em desvendar, movido pela curiosidade, todos os caminhos, no subjetivo, ela diz respeito à incapacidade de decidir por qual deles seguir. A dúvida subjetiva pode ser associada à equipolência, à impossibilidade de decidir por causa da indistinção, com uma diferença importante, se comparada com a suspensão do juízo, a incapacidade estaria no incapaz e não nas próprias aparências. A dúvida, nesse caso, é devastadora, porque o mal estar deriva e se aprofunda pela incapacidade de decidir, como numa espécie de gosto. Por outro lado, a dúvida subjetiva está ligada à certeza de que se tem uma dor. Daí numa apreciaçáo rápida se diria que o ceticismo se liga à dúvida objetiva e não à subjetiva. Dizer isso implicaria compreender o ceticismo tão somente como uma antecipação filosófica do espírito científico. Apesar das muitas afinidades, tal não parece ser verdadeiro, porque na ciência o dogmatismo é intenso. $\mathrm{O}$ ceticismo é equidistante aos discursos, mantendo sempre a atitude de ser coisa outra. Além disso, na dúvida, a separação entre objetivo e subjetivo não é tão evidente. A complementaridade entre os dois pode ser sentida tanto na comum afirmaçáo de que a objetividade não é confiável, pelo menos não plenamente, quanto na frustrada expectativa de que a objetividade resolva os enigmas da subjetividade. Em ambos os caminhos é o caso de incentivar a dor subjetiva, para que algo se resolva. $\mathrm{Na}$ desqualificação da objetividade, o sujeito resolve a dor pela afirmação de que nada pode ser conhecido pelos sentidos, de modo que se volta para dentro para encontrar o que procura. Ela leva o sujeito a se apegar à transcendência supostamente habitante de sua profundidade interior. A dor é mantida e não pode ser resolvida nem dentro e nem fora, mas a partir da instância transcendente que surge no dentro quando este não tem mais opostos. A dor faz aparecer o caminho. Se, por outro lado, a objetividade é valorizada, isso também implica que a subjetividade se resolva, senão pela transcendência, pelo menos pela descoberta de modos para se projetar de modo confiável sobre a experiência. Tudo isso para mostrar como a dúvida faz com que sujeito e objeto se impliquem: (I) tanto quando se duvida do sujeito, e se obtém objeto, quanto ao se duvidar do objeto e se tem o sujeito e (2) a partir do objeto, o sujeito alcança transcendência, ou, do objeto, o sujeito se convence da objetividade pura, como nas formas mais brutas de positivismo.

Privilegiamos isso que os anatomistas e os pintores têm em comum, que é a pictorialidade. A imagem fascina o cético. A aproximação inicial entre céticos e dogmáticos se dá porque este é um mestre da imagem. O interesse do cético é genuíno e não uma curiosidade por uma doença. A atração que o dogmático exerce sobre o cético nada tem que ver com a doença, e sim com a criação que pratica. É só depois 
que o cético percebe que o dogmático sofre, que é acometido justamente por sua bela capacidade, exageradamente, para muito além do plausível. O cético é fascinado pelo dogmático, porque esse, como dissemos, é um mestre inconsciente da imagem. O cético ama as imagens. Então ele as descreve, trata-as e as cura. Ele cuida de todos esses fragmentos que o dogmático espalha sobre o mundo. A habilidade terapêutica do cético, embora associada com aquela do médico, tem pouco para merecer a analogia, pois o que melhor ele faz é descrever a imagem de quem sabe bem produzi-la. Acontece que na criação desses objetos que brilham, os dogmáticos sofrem. A atividade do cético consiste em mostrar que a dor deriva do fato de crer que a imagem é a verdadeira. Ele mostra com imagens, a partir de imagens, que a verdade das imagens, no mais das vezes, equivale. O cético trata como um artista nos trata e o faz melhor quando não é percebido, ainda, cura melhor quando o suposto doente não sabe que é curado. Por essa razão não teria qualquer sentido instituir a diferença entre o normal e o patológico, ou tomá-la como critério para avaliar as imagens. $\mathrm{O}$ cético não é como um médico, ele é como um pintor. Aquilo que faz tratando, faria sem sofrimento em outras atividades.

Outra forma de perceber o problema da terapia como altruísmo, seria tomá-la como fútil, para dizer que, na verdade, o cético seduz ao admitir que ninguém pode fazer nada por ninguém, além de falar das próprias dores. Essa compreensão partiria do ceticismo como prática médica. Nela, então, algumas práticas de pensamento seriam o sintoma e a doença. Estranhamente, tomar práticas de pensamento dessa forma leva a julgar que náo há nada a fazer pelo doente. A forma mais comum de chegar a essa indiferença é hipostasiar a noção de discursos com sentido, de tal maneira que se tenha a predisposição de que aqueles a quem não se conhece de saída, não desencadeadores da sensaçáo imediata de familiaridade, carecem de sentido e precisam muito se esforçar para merecerem atenção. A conduta seria a de se fazer difícil, de escutar de forma aborrecida, de modo a ser o doente aquele que deve provar a sua saúde. Essa forma de compreender a terapia é absurda, posto que não cabe ao cético afirmar o sofrimento, mas ao doente dizer que se o tem. Assim, ao cético cabe esperar que todos os discursos possuam sentido no contexto a que pertencem, apenas concluindo pela falta de sentido de modo excepcional. Com mais razão, um discurso de sofrimento sempre detém sentido. De tal maneira que uma parte relevante do sentido está na disponibilidade de quem escuta. Apenas assim o ceticismo poderia ser compreendido como terapêutico, na medida em que possui disposição de acolhimento do discurso que sofre em seu sentido ${ }^{6}$. 6 "Além disso, para ser falso, um discurso tem que ter primeiro sentido e é sobre esse ponto que o ceticismo
terapêutico insiste: ele náo consegue apreender o sentido dos conceitos e das proposiçôs dos dogmáticos ou, 
Se "não consegue apreender o sentido dos conceitos e das proposiçóes dos dogmáticos", pode-se deduzir que tal se deve a um aborrecimento que impede a atividade terapêutica. Se a terapia é essencial ao ceticismo, tal indisponibilidade na busca do sentido impede o contrariado de ser cético. Diante daquilo que não pode entender, o cético toma a carência de sentido como uma falha sua e procura dela se livrar para poder ajudar aquele que sofre. A suspensão do juízo é realmente conforme a razão, mas de nenhuma ajuda seria se indicada de longe, sem envolvimento com o sofrimento ${ }^{7}$. Afinal, a suspensão não é genérica. Por certo que é um trajeto que se faz sozinho, porém isso não quer dizer que o cético não auxilie esse percurso. Ele o faz compreendendo o discurso de quem sofre, no sentido de adaptar as primeiras iniciativas para a suspensão do juízo, ao contexto do dogmatismo em questáo. Os dogmatismos são iguais no sofrimento, mas daí cada um sofre à sua própria maneira. O cético administra a suspensão de formas distintas, segundo relações terapêuticas singulares ${ }^{8}$.

Se se pode dizer que "[t]udo o que o cético terapêutico oferece é o caminho que ele próprio trilhou", uma forma de interpretar o dito seria no sentido de que faria referência ao que se atravessou na própria suspensão do juízo. Ou seja, o que tem para oferecer é o seu testemunho. Ele diria: - o que se passou comigo foi isso, logo, aquele que sofre é livre para fazer com isso o que achar melhor. Ainda, em outros termos, que o não reconhecimento se daria pela diferença dos jogos de linguagem. Então, uma forma de interpretar a sentença concerniria ao fato de que a própria ação da terapia é coerente apenas se se abandona a pretensáo de dissuadir aquele que sofre do seu sofrimento ${ }^{9}$. Parece-nos, todavia, que ela poderia ser compreendida de outro jeito. Ora, há muitas formas de se oferecer o caminho que se trilhou. Seria muito restrito julgarmos que oferecer a experiência é se colocar em narrativa individual de seu próprio caminho. O testemunho talvez seja a pior forma de oferecer os benefícios daquilo que se passou, justamente porque ele implica numa espécie de pegar ou largar. $\mathrm{Na}$ verdade, sejamos justos com as diferenças, mais em largar do que pegar. A relação com o testemunho é de assentimento, provocado pela qualidade da narrativa, respeitabilidade de quem fala, credulidade de quem ouve, ou combinaçóes etc.

o que é o mesmo, os dogmáticos não conseguem dar sentido ao seu discurso. E não se pode aceitar aquilo que não se consegue entender." (Smith, 2007, p. 5I)

7 “Todos deveriam suspender o juízo, se procedessem conforme manda a razão."(Ibid.)

8 "A terapia cética é, efetivamente, uma terapia múltipla, que se dirige a cada dogmático em particular e em funçáo dos aspectos próprios de sua doutrina." (Ibid., p. 52)

9 "Tudo se passa como se a terapia, para ser uma noçáo coerente com o próprio ceticismo, devesse ir abrindo mão da intenção de curar o dogmático.” (Ibid., p. 55) 
O terapeuta cético faz muito bem em abandonar a pretensão de cura no sentido médico, não no pictórico, uma vez que aquela concerne mais a um marco para agilizar a impaciência com relação ao doente, pois a noção médica de cura serve, sobretudo, para a resignação diante do incurável. O melhor que o cético pode fazer é acolher o dogmático em seu sofrimento e tal tem mais que ver com ouvir do que com falar. É o caso de suspender o juízo à cura, à doença, mas também à existência do doente. Ao ser provocado em sua capacidade de curar um dogma, o cético retorque com disponibilidade de escuta. Acolher um relato não é iniciar um debate, não se trata de um confronto de forças, mas a interação delas, não é uma luta, mas comprometimento corporal, segundo o qual o cético nem resiste e nem se entrega. Ele é ativo ou passivo na proporção para desarmar as resistências e depois aos dogmas, se na verdade não são um tanto a mesma coisa. Se a terapia cética fosse um confronto entre mestres cantores, em que a exibição serviria para estabelecer um derrotado, não estaríamos então diante de uma cena? Se assim fosse, o cético poderia muito pouco, porque nada saberia do outro, dentre outras razóes, por não estar exposto a nenhum risco.

Assim, o cético busca aprimorar as virtudes da escuta. Ele é aberto a descrever e tratar qualquer sofrimento, nisso um filantropo. Por essa razáo, escutar concerne a permitir que a maturidade da imagem dogmática termine em dissolução. Nesse sentido é que o cético descreve como um pintor e lida com os relatos como um curador. Se fôssemos escolher um campo semântico para a relação entre dogmáticos e céticos, ele estaria mais na ambivalência das dinâmicas amorosas, do que na ambiguidade frágil que não resiste nem bem à duração da batalha. Seria tão equívoco presumir que o cético náo manteria a tranquilidade da alma a cada um de seus movimentos de cura, quanto tomar a autorreflexáo como tendo algum valor na ausência do outro. Montaigne não apenas cura a si mesmo, porém o faz no contato com a cura que encontra para os outros com quem se imiscuiu. O fato de escrever sozinho, e sobre si mesmo, diz respeito à produção de um caderno clínico, que ao mesmo tempo em que depura a descrição, revisita o quáo bem (ou mal) sucedida foi a sua prática no mundo. Ninguém se cura sem curar. Ninguém se cura sem também assumir o risco de ser curado. Eu não me curo. Nós nos curamos.

A depuração das capacidades descritivas, o desbastamento das imagens, de modo a atingirmos os seus respectivos pontos de cura, tratá-las, pode muito ser reconhecido como uma parte da prática da crítica. Todavia, deve-se admitir que a crítica é precedida pela escuta. Se a tranquilidade fosse obtida apenas por se esquivar de ver ou ouvir, ou que uma vez obtida, dependesse da mudança do suposto cético para uma câmara sem som, seria inútil, porque ele se surpreenderia com o som das batidas do coração em seu peito e o ruído mais agudo das suas sinapses. A tranquilidade 
do cético tem valor, porque ele se faz imerso entre aqueles a quem pode ajudar, mesmo quando não querem ser ouvidos, o que é raro. Um cético se diferencia de um dogmático por subordinar sua fala à sua capacidade de perceber. $\mathrm{O}$ ceticismo visa produzir mestres da recepção e enunciadores incidentais. $\mathrm{O}$ cético quando enuncia encontra sua forma de o fazer de modo a permitir que sua imagem se esquive do sofrimento. Se retirado na floresta, ele não o faz para viver a tranquilidade sem risco, mas para reencontrá-la em outro ambiente ${ }^{10}$.

Este é um ponto importante da sedução exercida por essa forma de terapia, encontra-se no cético alguém disposto a entrar em uma aventura não pelo gosto por ela, mas porque o outro precisa que ele assim o faça. Costuma-se dizer que nada é mais certo do que a própria dor e nada mais incerto do que a dor do outro; toda a questão da sedução filantrópica é inverter esse preconceito. Se o outro sofre, ele deve ser descrito em suas nuances. A descrição não precisa assumir forma de enunciado. O fundamental mesmo é que o cético esteja na posição de poder descrever. Dessa forma, torna-se cada vez mais nítido que a sedução exercida pelo cético deriva de seu autoconhecimento. $\mathrm{Na}$ maior parte das vezes, entende-se por autoconhecimento, ora, o conhecimento do Eu. Os elementos que tornam o eu próprio e o modo pelo qual os acidentes imprimem marcas distintivas no sujeito. O saber de si entregaria a dinâmica de se tornar si mesmo. Se assim fosse, tomar o exercício terapêutico como o momento em que o cético fala de si para quem quiser escutar, de modo que a compreensão mútua se daria por analogia, faria todo sentido. Seria tal como numa daquelas conversas em que cada uma das partes fala apenas de si, apenas esperando a oportunidade, para que os dois, ou mais, não falem juntos. Uma tal forma não seria muito produtiva, muito menos em uma situação terapêutica. Quem sofre, possui necessidade de falar de si, certo que está da sua dor, cabe ao cético dar oportunidade para que o dogmático fale sozinho, para que essa certeza comece a se quebrar por seus próprios meios. Independente de estabelecer uma narrativa de autoconhecimento, está claro que o cético, para poder ajudar, dele precisa. Há momentos em que pode parecer que enuncia como quem faz uma confissão, para escapar dessa captura, porque busca coerência, realiza imersão na inovação formal, para que seja capaz de falar sem fazer asserçôes, ou ser afásico sem se calar ${ }^{11}$. O ensaio, como gênero enunciativo eminentemente cético, é uma das chaves para compreender tal procura, mas menos pela forma história e mais pelo gesto que implica. Fazendo-o, pode ajudar a outros no percurso que realizam, mas se a terapêutica se reduzisse a falar de si, seria como publicar charadas escondidas no jornal, no anseio que alguém

\footnotetext{
${ }^{10}$ Smith, 2007, p. 55-56.

${ }^{11}$ Bicca, 2012, p. 198, 205.
} 
as decifre para poder encontrar. Mais ainda, que a pessoa certa o faça. Ora, quem sofre é sempre a pessoa errada ${ }^{12}$.

O autoconhecimento do cético náo nos parece que diga respeito ao eu particular, mesmo quando expressamente diz que sim. Isso porque o eu particular é táo ficcional quanto o "eu geral", ou o espírito da coletividade. A direção do autoconhecimento do cético é justamente o desfazimento do Eu. Se conhece para desaparecer e conhecer o outro e ajudá-lo no próprio processo de desaparecimento. Parece-nos que é equívoco ler Montaigne ou Bayle como estabelecedores de narrativas sobre o eu particular, quando o que enfatizam é a dimensão radical da alteridade, de que somos de tal forma povoados do que se distingue de nós, que tomar tal feixe de sensaçóes como particular, lembra mais a uma convenção. A preocupação do eu particular é ter ideias.

Montaigne com suas paisagens e Bayle com os seus retratos estão muito mais se desfazendo do que tornando o Eu particular. Se podemos nos curar lendo Montaigne ou Bayle, sem precisar de mais nada, é porque nos preparam, por assim dizer, ao abandono de nós mesmos. O ceticismo consiste numa "emancipação com relação ao egoísmo", na "aboliçáo da subjetividade", muito mais do que à "construção de uma fortaleza interior" (Bicca, 2012, p. 207). Não se trata de um monólogo do Eu, mas na "consagração e [...] neutralização da mente por ela mesma". "[N]ão se trata apenas de transformar, para reforçar, o "eu", mas de destruí-lo pouco a pouco, pacientemente [...]” (Ibid., p. 209).

A última, mas não menos importante atividade em que o ceticismo exerce a sua sedução, é a política. A chave de sua especificidade reside na consciência de se dever lidar mais com a política, tal como estrutura a vida social, e menos pelo que se espera dela. A disposição de transformar um estado de coisas pela política tenderia a tornar opaca a percepção moral dos seus impactos negativos. Os pretendentes a transformadores da política não agem, via de regra, com total clareza do sentido de suas práticas. Isso, por outro lado, não as torna menos cruéis. A sedução exercida pelo ceticismo na política concerne a se preocupar mais com crueldade derivada da manutenção do estado de coisas, e a pressuposta nas metas de mudança do mundo, e não propriamente com o ânimo implicado na vitória contra o suposto oponente. O ceticismo é sensível à crueldade e nota que a política não só por ela se caracteriza como náo a toma por problemática, em alguns momentos até mesmo a sugerindo, donde a especial atenção que a ela precisa dedicar, descrevendo-a.

\footnotetext{
12 "Os argumentos que ora exponho não querem persuadir nem dissuadir; eles estão aí para serem corrigidos por quem quiser corrigi-los” (Smith, 2007, p. 63). A questão, todavia, não parece ser estar certo ou errado. Mas estar ou náo disposto a ajudar.
} 
O ceticismo seduz expondo o que a política esconde, o fato da crueldade se tornar cada vez mais profunda e opaca, principalmente, se não é descrita, isso ocorre em virtude dela, a título de produzir estabilidade, aumentar as doses do sofrimento que, se examinado de modo atento, seria tido por insuportável. A aproximação do cético à política não se deve à vontade de poder, porém, justamente, à sua ojeriza à crueldade. A física por ele identificada é que a política deixada à própria sorte se cristaliza entorno da ação viciosa, donde a forma narrativa que, para abrandar o processo, deixa-a sempre à vista. A dinâmica, pelo cético percebida, é que o enunciado de melhoramento moral da política, feito de modo direto, costuma ser ruim, porque desperta resistência, donde preferir a descritividade da crueldade, porque esta boicota as maneiras de camuflagem, passando desapercebida, e aparece como adequada, ao que pode ser considerado como diminuição deste tipo de sofrimento. A sedução política, exercida pelo cético, consiste em mostrar, em sua performance, que a virtude, como instituição política menos cruel, é possível. Isso não quer dizer que o cético se coloque na posição de almejar, necessariamente, esses efeitos. $\mathrm{O}$ cético descreve a crueldade independentemente deles: o que só aprofunda o efeito sedutor. Ao mesmo tempo em que não parece crível um mundo em que não haja crueldade para ser descrita.

Pode-se dizer que a crueldade é para a ação o que o dogma é para o pensamento. Se o dogmático sofre por existirem muitas versôes, em disputa, da verdade, o cruel sofre porque há muitas alternativas à crueldade. As muitas versóes do mundo aparecem ao cruel como uma oportunidade à estabilidade pela crueldade. $\mathrm{O}$ fato de que elas insistem e se atualizam o faz sofrer. Não parece existir uma forma de crueldade natural para consolidar cada tipo de mundo. O cruel estaria disposto a se convencer que é possível encontrar tal confluência, adequada com naturalidade à situação, mas não deixaria de sofrer diante das alternativas, da concorrência e da possibilidade de estar errado. Ele sabe o que está para ser visto, que a crueldade oferece mecanismos previsíveis, mas não é capaz de controlar o mundo que surge a partir de cada tipo específico. Isso quer dizer que o cruel lida apenas com os efeitos superficiais de sua prática, sem se importar com a existência de uma dimensão interna da crueldade presente, que é capaz de se cristalizar, inclusive em estratos cada vez mais profundos. A demanda de que o mundo tenha mais ordem costuma derivar do alheamento à dinâmica restritiva. Julgar que o mundo precisa de mais crueldade, devese a não se conseguir sentir, ignorar, nesse sentido, o quanto ele é repleto dela. Se não se pode, por incapacidade, diminui-la em sua intensidade, que, pelo menos, seja conservada, como está, e que náo se a renove. O cruel sofre pela precariedade da prevalência da restriçáo em seus termos, e a pluralidade serve para atrapalhar a sua 
vida, porque acaba por indicar que as crueldades, tais como os dogmas, quase sempre se equivalem ${ }^{13}$.

Além do trabalho de ter que se tornar capaz de descrever a crueldade, acompanhála, mesmo em suas vilosidades arqueológicas e genealógicas, é preciso que o cético faça sua atividade ter um efeito terapêutico, incidental, sobre o dogmático. A consciência sobre o que é possível ou não fazer pelo mundo e pelo cruel é dependente, a nosso juízo, da distinção entre violência e crueldade. A violência é a destruição, que implica dor, causada de modo voluntário ou involuntário, predominantemente imprevisível. A crueldade, por sua vez, justamente pelos efeitos restritivos e constritivos que a caracterizam, precisa estar relacionada à previsibilidade. A ação cruel, nesse sentido, prolonga-se no tempo, dando condição para que a simples dor se transforme em sofrimento. $\mathrm{O}$ mal da crueldade começa com a dor, como na violência, porém se consolida num sentimento duradouro. A violência e a crueldade são vícios, males, porque dores. A especialidade da crueldade enquanto vício, que está dentre as razóes pelas quais pode ser considerada um vício pior do que a violência, deriva do natural efeito de ocultamento que exerce ao redor de si ao insistir em sua duração. A continuidade a torna imperceptível. Assim, apesar das semelhanças, e da região de penumbra e indeterminação entre as duas, de maneira a um conjunto significativo de fenômenos não permitir que decidamos se são violentos ou cruéis, uma vez estabelecida a predominância, é fácil as distinguir. Da mesma forma é passível de identificação o uso instrumental da violência em virtude da busca por efeitos previsíveis.

Parte da seduçáo exercida pelo cético em âmbito político é, como dissemos, a sua intolerância à crueldade. Ela precisa ser compreendida mais como, por exemplo, a intolerância à lactose e menos como a religiosa. A crueldade lhe parece odiosa, podendo ser considerada o mais terrível dos vícios, mas é menos algo que o cético pensa e mais o que sente. É longa a lista de céticos que ajudaram a perceber o ceticismo como dotado desta especial sensibilidade. Mais ainda, é possível que o ceticismo seja responsável pela expressão linguística desse modo de sentir. Os mais relevantes são Montaigne, Bayle e Hume. A política se apresenta como um evento restritivo, de efeitos subjetivos constritivos, cuja maneira mais sintética de indicar remeteria ao que convencionalmente é entendido por crueldade. Pelo fato do cético ter horror à crueldade é comum achar que este não se dedica a pensar a política. Esta é a chave pela qual o ceticismo, ora mais à direita, ora mais ao centro, é encerrado em uma cor ideológica específica. A iniciativa, para variar um pouco, costuma ser mais representativa de quem o faz do que do ceticismo, uma vez que, sendo a ele

${ }^{13}$ Laursen, 2004, p. 212. 
simpático, o intérprete lhe reputa sua própria preferência, e o inverso, no caso de tê-lo como adversário. Assim, faz pouco sentido reduzir a presença da preocupação política do ceticismo com a suposta posição política do cético. Seja lá onde estiver, ele obedece às leis da cidade e descreve a crueldade do estado de coisas.

$\mathrm{O}$ cético, ao descrever, aponta a política como um momento da experiência e não toda ela. A política está na manutenção da dor por certo espaço de tempo. Por quanto tempo? É evidente que uma medida válida a qualquer circunstância é impossível. Daí é que se pode dizer que a política pode politizar, até mesmo, a fatia que abocanha da experiência. Isso acontece, por exemplo, quando o âmbito da previsibilidade é retraído para induzir a indiscernibilidade entre a crueldade e a violência. Uma parte importante da sedução exercida pelo ceticismo na política é o desarmamento da captura da política por discursos privilegiados. Não porque a política, supostamente, deva ser deixada solta, mas pela dupla crueldade da vedação do acesso à política e do perigo da semântica política ser definida de modo não descritivo, de acordo à conveniência dos interesses. A seduçáo cética na política é especialmente intensa ao indicar que subtrair a política ao político é vicioso, principalmente, por duas razóes, por esconder a vontade de poder e por expor a sociabilidade ao livre aprofundamento da restrição, e seus efeitos constritivos.

O ceticismo põe a sua capacidade descritiva à disposição da sociabilidade e tal ocorrência se deve à sua sensibilidade não o deixar perder a crueldade de vista. A vida social, por outro lado, convoca o cético a dinâmicas de participação. Nesse âmbito, a questão é saber se ele é capaz de sustentar a intensidade de sua sedução descritiva. Em outras palavras, se ele seria talentoso a ponto de ser táo sedutor nas atividades pelas quais se é capturado, quanto naquelas em que se vale da esquiva para ver melhor. Em algum momento, a despeito de nossas vontades, somos obrigados a participar da crueldade. Soa improvável a capacidade de manter a força descritiva necessária à sedução nesses momentos. Isso vale, igualmente, para as posiçôes de resistência, em que os modos da crueldade são disputados, reivindicados, acarretando na expansão da política.

Nessa mesma seara se póe a interrogação sobre como o cético se comportaria nas mãos de um tirano. A concepção comum é que um soldado, um político, um magistrado, um professor, ou mesmo o mecânico de automóveis ou o motorista, desempenhariam melhor as suas funçóes se investidos de um valor que as ultrapassasse. Se isso fosse verdade, se o desempenho de uma atividade é melhorado na presença de uma crença, entáo o cético seria invariavelmente ruim em qualquer coisa, ou pior do que os outros. Náo é necessário muito esforço da imaginaçáa, e nem tanta recolha de eventos da experiência, para considerar tal opinião insensata. É admissível 
que certas atividades se tornam mais comuns a partir da adesão de um número considerável de pessoas, bem como, a essas passarem a ter um vínculo existencial com ela. Nem mesmo a dinâmica descrita nos faz concluir que a mesma atividade poderia ser táo bem executada com ou sem crença nela, ou na sua importância. Uma atividade é bem executada quando a pessoa que a faz tem prazer em fazê-lo e possui a formação e o talento necessários. A crença na atividade pode tanto ajudar quando atrapalhar. É mais crível que o desempenho seja pior quão mais se tenha a ação como muito importante e difícil de ser concluída. Não se ter uma crença sobre ela, dependendo da situação, pode mais ajudar do que atrapalhar. Além do que, as atividades existem porque se precisa delas e não porque se crê nelas. A crença, nesse caso, parece ser mais um efeito colateral da necessidade. A manutenção da atividade, nos termos em que se a conhece, é dependente do sistema de crenças, porém não é o caso da boa execução. Um cético pode não ajudar a manter uma prática para além da sua necessidade, mas possivelmente é capaz de realizá-la tão bem quanto qualquer um. Nas mãos de um tirano, um cético se comportaria tấo bem ou táo mal quanto qualquer um. A vantagem do cético é que não suporta a crueldade e não torna $o$ hábito de obediência em crença. Nada melhor do que ser omisso na prática da crueldade e diligente na sua denúncia e combate.

Em âmbito político, o cético é considerado suspeito, porque sua ação não pode ser prevista. O dogmático, a partir de suas crenças, é previsível no que concerne ao habitual. Por outro lado, a crença de que se seria capaz de morrer pela democracia ou pela república náo indica de nenhuma forma que o comportamento aconteceria quando chegasse o momento. A percepção do que se é capaz de fazer para resistir é completamente diferente daquela sobre as capacidades para cooperar. Donde, alguém que considere desejável obedecer um tirano, usando a palavra de modo alusivo, dificilmente faria alguma coisa para facilitar a tirania, se a ação implicasse risco, mas correria para cooperar caso a transiçáo acontecesse. Isso nos leva a pensar que a crença é importante para prever obediência, porém não para antecipar habilidade ou desobediência.

No Contra os Éticos, Sexto aborda a questão. Um tirano pode obrigar um cético a cometer uma ignomínia sob pena de tortura. O senso comum, sobre o ceticismo, espera que, como não há crença, livrar-se da dor seja o mais conveniente. Em suma, um dogmático seria previsivelmente bom ou mau e o cético, por não ter crenças, inclinar-se-ia ao mais cômodo. A resposta de Sexto é que o cético obedecerá, ou não, aceitará, ou não, a tortura, segundo, não as crenças que têm, porque não as têm, mas 
a de seus ancestrais ${ }^{14}$. O dogmático, e seu valor, não sabe o resultado do conflito entre o medo e o medo de ser menor do que espera ser, porém julga que sabe. O cético do Sexto teria um critério mais factível de ser seguido, porque não sentiria o valor do critério, apenas o repetiria. Laursen vai ainda mais longe e imagina uma situação pior ${ }^{15}$. E se o cético é capturado por um tirano que impóe que se torne um parricida sob pena de perder a vida? O dogmático, além da ansiedade, sobre sua própria capacidade de estar a altura do que espera de si mesmo, quando chega o momento, tendo um valor pronto para a situaçáo, ou mataria o pai ou perderia a vida.

O que permitiria o dogmático ter tanta certeza da sua ação a partir da crença? Ele espera, aventaríamos, ser possível preparar-se para um evento moral exigente de modo semelhante a uma prova esportiva ou de memorização. A esperança seria que a repetição, para si, da reação que se espera desempenhar no futuro, aproximaria a crença de sua realização à medida. A solução de Sexto não é completamente crível, tão pouco a do dogmático, e, curiosamente, convergem para um núcleo, isso porque, sem crer, a relação com os antepassados é tênue, e repetir para si é distintivo de querer se sentir pronto, não de estar pronto. $\mathrm{O}$ equívoco está em julgar que a repetição dos costumes ou das ideias, sob estratégias diferentes, através da exposição controlada às situações, permitiria o controle da ação, simplesmente como um comportamento, ou pelo vínculo com a crença. Se isso é verdadeiro para uma série atividades, não parece ser possível para situações moralmente desafiadoras. Se as certezas morais são desafiadas, não há como prever como nos comportaremos. É isso que as faz desafiadoras. A seduçáo do cético ao lidar com os impasses é indicar que, tal como todo mundo, não sabe como reagirá ao ser obrigado a se comportar cruelmente. Não sabe e não pretende que sabe.

Se não há como antecipar a reação diante de um evento moralmente desafiador, se agir mal numa situaçáo, como a aventada, diz pouco sobre a moralidade da pessoa, deveríamos esperar qualquer coisa? A questão é posta em outros termos pelo cético. A busca pelos benefícios, se possíveis, de estar preparado para um impasse, são justificáveis se somos capazes de saber o que é o melhor. Nada impede que a circunstância mostre que o que achávamos ser o melhor é o pior. Um mundo em que somos obrigados a matar os nossos pais é provavelmente pleno de interpelaçóes parecidas ou piores. O cético reformula a questão, ao invés de perguntar sobre o que devemos fazer no momento do desafio, ele demanda sobre o que precisamos fazer enquanto o dilema não acontece, uma vez que pouco podemos fazer para nos preparar para ele. O que fazer antes do momento de agir?

\footnotetext{
${ }^{14}$ Empiricus, 2006, p. I64-I66, 463-465.

${ }^{15}$ Laursen, 2004, p. 209.
} 
A sedução exercida pelo cético, em âmbito político, concerne ao acúmulo descritivo que oferece como profilaxia à restrição. Ele descreve sistematicamente a crueldade, antes que ela redunde em impasses. A ojeriza faz com que não consiga se distrair da sua presença. Ele a segue nos rostos e paisagens que viu outras vezes, porque sofrem alteraçóes constantes. A restrição está de um jeito e depois está de outro. Mas também o faz com relação às fisionomias e sítios desconhecidos. A mistura a ser consolidada para o evitamento do abismo moral é feita de perspectivas acumuladas. Ela serve principalmente para se acompanhar a política em diferentes fenômenos. Isso porque o aprofundamento descritivo acaba por apontar que a política pode estar em qualquer lugar, mas que nem tudo é política. Isso quer dizer que ela é um modo de diferentes experiências. A política é a modalidade de restrição, de efeitos constritivos, que pode estar e depois deixar de estar em qualquer fenômeno. Trata-se de um estado, um momento, dos eventos. $\mathrm{O}$ cético pretende que a sua prática sirva de índice para que outros encontrem a política onde ele não a conseguiu ver e a acompanhar nas dissimulaçóes realizadas para poder se aprofundar. As coisas mudam inevitavelmente. A política é a maneira pela qual as pessoas se rebelam contra este processo. $\mathrm{O}$ assombro do cético é que faça sentido obter estabilidade à custa de tornar a dor sofrimento e instituição.

O cético quer mostrar o rosto dos investidos em assegurar o hábito enquanto sentem prazer com a dor do outro. É pelo retrato, pela comparação de fisionomias, conceitualmente falando, que melhor se nota como as restriçóes se relacionam com os sentimentos. Para isso precisa caracterizar também a paisagem em que esses rostos são encontrados. As perspectivas precisam oscilar em posição, porém, igualmente, em distância. Sem tal circulação não há como compreender, como, por assim dizer, as fisionomias são fabricadas, como dissimulam a crueldade que possuem. A restrição é passível de ser desvendada pelo movimento que as pessoas são induzidas a realizar pela cidade, por exemplo, como mudam ao passarem por tal ou qual ponto, em suma, é preciso entender o longe, por vezes, para que o perto faça sentido, é preciso conjugar dinâmicas mais amplas como o gesto e o rastro, com outras mais minudenciosas como o rosto e a voz.

O acompanhamento descritivo da crueldade ajuda a identificar os sentimentos ambivalentes como indícios da politicidade. É isto que o rosto mostra: há prazer com a dor do outro, mas também há dor. A avaliação moral da política não pode simplificar o que não é simples. Há dor e prazer na restrição e dor e prazer em ser restringido. Assim, se incapaz de conhecer a paisagem na qual se debruça, tendo que se guiar, inicialmente, pela fisionomia dos passantes, a experiência acumulada do ceticismo, a sua tradição, acabaria por recomendar o começo da descrição pelos eventos de incomum intensidade ambivalente. Se nem toda ambivalência é política 
é certo que onde há política existe ambivalência, principalmente, em virtude da troca de sofrimento por estabilidade e previsão dos acontecimentos sociais. Além do que, é muito comum que haja descompasso entre o que se faz e o que se diz sobre o que se faz, donde a necessidade de conjugar o discurso ao rosto. Em muitos momentos em que se diz que se faz o bem, a fisionomia de quem o recebe parece indicar o contrário. É preciso que essas comparaçôes sejam feitas para que as enunciaçóes não dissimulem o vício que se está a seguir.

O cético seduz ao dizer que constata que não há problema em não se saber como agir em uma situação extrema, desde que se faça o dever de casa de mapear a crueldade, para impedir seu aprofundamento, além de indicar estratégias para minimizar o sofrimento, por nos sentirmos inseguros, ao nos termos incapazes para o impasse, posto não haver uma forma correta de se comportar. Mais ainda, que os que se sentem preparados, ostentando segurança, estão mentindo para si próprios, porque é próprio do momento excepcional horizontalizar as inépcias. A virtude serve pela regularidade que oferece, desde que tratados os efeitos colaterais da crueldade, porém, ao mudarem drasticamente as circunstâncias, é um mistério o que as pessoas farão dos antigos valores cultivados. A sedução do cético em âmbito político é auspiciosa porque oferece uma alternativa à arrogância da suposta sapiência sobre o que deve ser feito, que, na verdade, só serve para conceder autoridade indevida em tempos mais tranquilos. As opções sobre o que poderá ser feito para antecipar as açôes, equivalem-se em opacidade. Talvez por isso, em se ignorando a particular maneira pela qual o cético cumpre regras, se o aproxime, às vezes, ao afeto conservador, porque o melhor a ser feito, no mais, é seguir as leis da cidade, depurar as tradiçóes, desviá-las da restrição desmedida, sobretudo, acumular algum domínio sobre os efeitos mais viciosos e seus antídotos já testados. O cético é sedutor porque sugere que a cidade precisa ser tornada menos afeita à novidade política.

A efetividade da sedução cética em âmbito político rapidamente se dissolveria se os estratos da sua descrição fossem interrompidos. $\mathrm{O}$ retrato não apenas mostra a ambivalência, que serve de índice para se encontrar o estado da politicidade, quando acontece, ele permite, outrossim, que se tenha um âmbito mais afunilado para se especular sobre a crença da qual a fisionomia depende. A investigaçáo do rosto pode revelar igualmente a vontade de sistema do retratado. Ousaríamos dizer que a vontade de sistema está para o rosto, enquanto denunciadora da crueldade, como a dinâmica entre a restriçáo e a indução do movimento está para a paisagem. Isso quer dizer que a fisionomia que denuncia a presença da vontade de sistema apresenta disposição incomum à crueldade. $\mathrm{O}$ cético é sedutor por auxiliar na reprovação ao rosto com um sistema. Porque neste há arrogância para indicar o que as relaçóes devem ser, como as pessoas precisam se comportar em face do extremo, donde o 
infundado aprofundamento da crueldade, tornado possível pela irresponsabilidade enunciativa acerca de modos futuros, sobre os quais não há como saber.

A descrição praticada em âmbito político, pelo cético, cujo objetivo é desalojar a crueldade que se esconde, tanto na paisagem, quanto nos rostos, impedindo o seu aprofundamento inconsciente, acaba por apresentar uma curiosa continuidade entre as imagens estabilizadas e a consciência que o cético tem de possuir acerca da composição da imagem. O cético destrói e sabe como as imagens se constroem. Noutras palavras, precisa ser um pictorialista para ser capaz de mostrar o imprescindível. Isso quer dizer que ele inaugura um campo construtivo, dos modos de fazer mundos, uma vez que para mostrar a montagem é necessário entender a fabricação. A derradeira seduçáo do cético, em âmbito político, consiste em evidenciar, com a sua prática, que, por trás da passividade descritiva, está uma imaginação que compreende os modos da instituição. Nada mais curioso do que o movimento incessante do que está aparentemente imóvel. O domínio da gramática construtiva, para além do apelo exercido pela entrega da unidade interna do sistema, tal como oferece quem é movido pela vontade de sistema, dota o cético da capacidade de seguir os atalhos utilizados pela imaginação para adquirir coerência, os truques de falsificação da realidade, e recomendar hesitação diante da retórica da necessidade. Mais importante do que a mudança voluntária é a certificação de que esta se institua pela minoração da crueldade e náo para adicionar opacidade aos seus meios. A atençáo às paisagens de crenças, depois aos rostos em situação de exercício restritivo, aos sistemas de crenças elaborados, à lógica pela qual a cidade fabrica as pessoas induzindo o movimento que realizam etc. fornece os átomos pictóricos que compóem as imagens que o cético utilizará na articulação do mundo com suas paisagens e rostos. O pictorialismo do cético não é literal. A literalidade descritiva não é suficiente para fazer a crueldade aparecer, porque esta não é evidente ou transparente. É indispensável que pinte de modo a que a vida descrita possa ser sentida.

\section{Referências bibliográficas}

Annas, J. (1983). The Morality of Happiness. Oxford: Oxford University Press.

Aubenque. (1973). "As Filosofias Helenísticas: estoicismo, epicurismo e ceticismo." In: A Filosofia Pagã. Rio de Janeiro: Zahar.

Barnes, J. (1998). "The Beliefs of a Pyrrhonist." In: The Original Sceptics: a controversy. Cambridge: Hackett Publishing Company.

Barthes, R. (2003). O Neutro. São Paulo: Martins Fontes.

Bernhard, T. (20II). "Montaigne: uma narrativa”, Serrote_(7), pp. 23I-238.

Bicca, L. (20I2). "Ceticismo como Terapia." In: Ceticismo e Relativismo. Rio de Janeiro: 7 Letras. 
Burnyeat, M. (1998). "Can the Sceptic Live his Scepticism?" In: The Original Sceptics: a controversy. Cambridge: Hackett Publishing Company.

Empiricus, S. (2006). Against Ethicists. Cambridge: Harvard University Press.

Laursen, J. C. (2004). "Yes, Skeptics Can Live Their Skepticism and Cope with Tyranny as Well Anyone." In: Skepticism in Renaissance and Post-Renaissance Thought. New York: Humanity Books.

Smith, P. J. (2007). “Terapia e Vida Comum. ”Sképsis I(I). 